\title{
Studies on the Visual Acuity of Pigs Using Shape Discrimination Learning
}

\author{
Toshio TANAKA, Yumi MURAYAMA*, \\ Yusuke EGUCHI and Tadashi YOSHIMOTO \\ School of Veterinary Medicine, Azabu University, \\ Sagamihara-shi 229-8501
}

(Received October 9, 1997)

\begin{abstract}
The objective of this study was to determine the visual acuity of pigs. Six pigs were trained to discriminate between a Landolt ring and an ordinary ring of equal size associated with feed. The left and right positions of the 2 targets were shifted according to the Gellermann series. After the pigs were fully trained, their visual acuity was determined by changing the size of the rings or the distance from the target. The pigs were subjected daily to 1 or 2 sessions which consisted of 30 trials each. The criterion of successful discrimination was 3 consecutive sessions with more than 21 correct choices $(\mathrm{P}<0.05$, Chi-square test). Two castrated pigs were not able to learn the experimental procedure. The best scores of visual acuity in the 4 female pigs were $0.017,0.034,0.035$ and 0.07 .
\end{abstract}

Anim. Sci. Technol. (Jpn.) 69 (3) : 260-266, 1998

Key words : Pigs, Visual acuity, Discrimination learning, Operant conditioning

It is important to understand the function of sense organs in farm animals and thereby improve management. In recent years, some reports dealing with the application of the sensory and learning ability of animals to their management have been published. For example, Entsu et al. ${ }^{5)}$ studied the improvement of methods for tending cattle by conditioned sound. Manda et al. ${ }^{14)}$ investigated the response of cattle to variously colored electric fences in order to apply sensory capability to the management of grazing animals. Sheep have also been able to discriminate between different colors and have been expected to utilize this ability to control their behavior ${ }^{21,22)}$. Visual acuity of ruminants was also studied and reported that the score for Japanese Black cattle and Holstein cows was between 0.04$0.08^{7,15)}$. We showed that the visual acuity score of sheep was between $0.085-0.19^{23)}$. On the other hand, studies on the visual sense of pigs were very few. Color vision of pigs and wild boars was reported by Tanida et al ${ }^{24)}$ and Eguchi $e t a l^{4}{ }^{4}$, but the visual acuity of pigs has not been studied yet.

The objective of this experiment was to study the visual acuity of pigs by shape discrimination learning.

\section{Materials and Methods}

Three Large White female pigs (Pig 1-3:2 months old) and 3 crossbred (Large White $X$ Duroc) pigs, 1 female (Pig $4: 3$ months old) and 2 castrated male (Pig 5,6:3 months old), were used. The pigs were kept in individual pens and provided with only $50 \%$ of the nutrient requirements according to the Japanese Feeding Standard for Swine ${ }^{13)}$ of formula feed (CP

* Present address : Training Farm, National Federation of Lívestock Agriculture Cooperative Associations, Nishinasuno-machi, Tochigi-ken 329-2747 
$15.5 \%$, TDN $77 \%$ ) at $17: 00$ in order to ensure sufficient feeding motivation. Water was available $a d l i b$. in the pen.

The experimental apparatus is shown in Fig.

1. A Landolt ring and an ordinary ring of equal size were the negative and positive visual targets, respectively. The ring was black on a white background and covered with a clear board of acrylic resin. The targets were hung on the wall above each switch. When the switch below the positive target was pressed, 5 pieces of small cookies were delivered. The visual targets were illuminated by halogen lamps. Light intensity on the visual targets was 500-550lux during the discrimination training and testing.

At first, the pigs were habituated to the experimental apparatus and learned the association between the switch and the reward (Training 1). The next training was conducted by using only an ordinary ring (Training 2). One training session consisting of 30 trials was done daily, and finished when the pigs completed 3 consecutive sessions with more than 21 correct choices $(\mathrm{P}<0.05 \text {, Chi-square test })^{20}$. Pig 5 and Pig 6 were very disturbed in the experimental apparatus even in training 1 and were not able to reach the criterion in training 2. Therefore, these two pigs were excluded from the experiment. In the following training (Training 3), the pigs were trained to discriminate between a Landolt ring (Pig 1 and Pig 2:318 $\mathrm{mm}$ in overall diameter with $64 \mathrm{~mm}$ ring and gap widths; Pig 3 and Pig $4: 321 \mathrm{~mm}$ and $64 \mathrm{~mm}$, respectively) and an ordinary ring of equal size at a distance of $3.6 \mathrm{~m}$ (Pig 1 and Pig 2) or $3.0 \mathrm{~m}$ (Pig 3 and Pig 4), which corresponds to a visual acuity score of 0.017 (Pig 1 and Pig 2) or 0.014 (Pig 3 and Pig 4).

After the pigs were fully trained, their visual acuity was determined by changing the size of the rings or the distance from the target ${ }^{12.18}$. The pigs were subjected daily to 1 or 2 sessions consisting of 30 trials. In each trial, the door of the waiting box was opened, and the pig went into one of the choice alleys. The pig returned to the waiting box after pushing the switch. The choice was recorded when the pig put its foot in to either the left or right alley. There was no case that the pig did not enter the alleys. Each session started at $09: 00$ or 14 : 00 and ended within $1 \mathrm{~h}$. Each trial was conducted at intervals of $15 \mathrm{~s}$. The arrangement of the targets in each trial was changed according to the Gellermann series ${ }^{9)}$ during the interval time. The criterion of successful discrimination in each visual acuity score test was 3 consecutive sessions with more than 21 correct choices in 30 trials until the 15 th session ${ }^{24)}$.

\section{Results}

During the second training period using only an ordinary ring, it took 4-12 sessions for the pigs to learn the relationship between a positive target and a reward. In the subsequent discrimination training between the Landolt and ordinary rings, the pigs performed very different responses. Pig 1 reached the learning criterion after the 8 th session. In Pig 2, however, the correct choices were more than 21 trials in a few sessions but no 3 sessions were consecutive until the 74 th session. Therefore, the length of the choice alleys was shortened to $1.8 \mathrm{~m}$ (visual acuity score : 0.0085). Then, Pig 2 reached the learning criterion after the 14th session. As Pig 3 and Pig 4 were not able to reach the criterion during 15 sessions, the gap of Landolt ring was enlarged to double widths. After Pig 3 and Pig 4 were fully trained by the modified rings during 8 (Pig 3 ) or 26 (Pig 4) sessions, both pigs were tested again using the original rings and were able to discriminate them in the first 3 sessions.

The results of the discrimination test for Pig 1 and Pig 2 are shown in Table 1. Pig 1 reached the criterion of successful discrimination by the 8 th session with a visual acuity score of $0.017-0.03$. In the case of 0.035 , the correct responses amounted to more than 21 trials $(70 \%)$ in only the 13 th session, but there 
TANAKA, MURAYAMA, EGUCHI and YOSHIMOTO

Table 1. Rate of correct choices of Pig 1 and Pig 2 in varying visual acuity scores (\%)

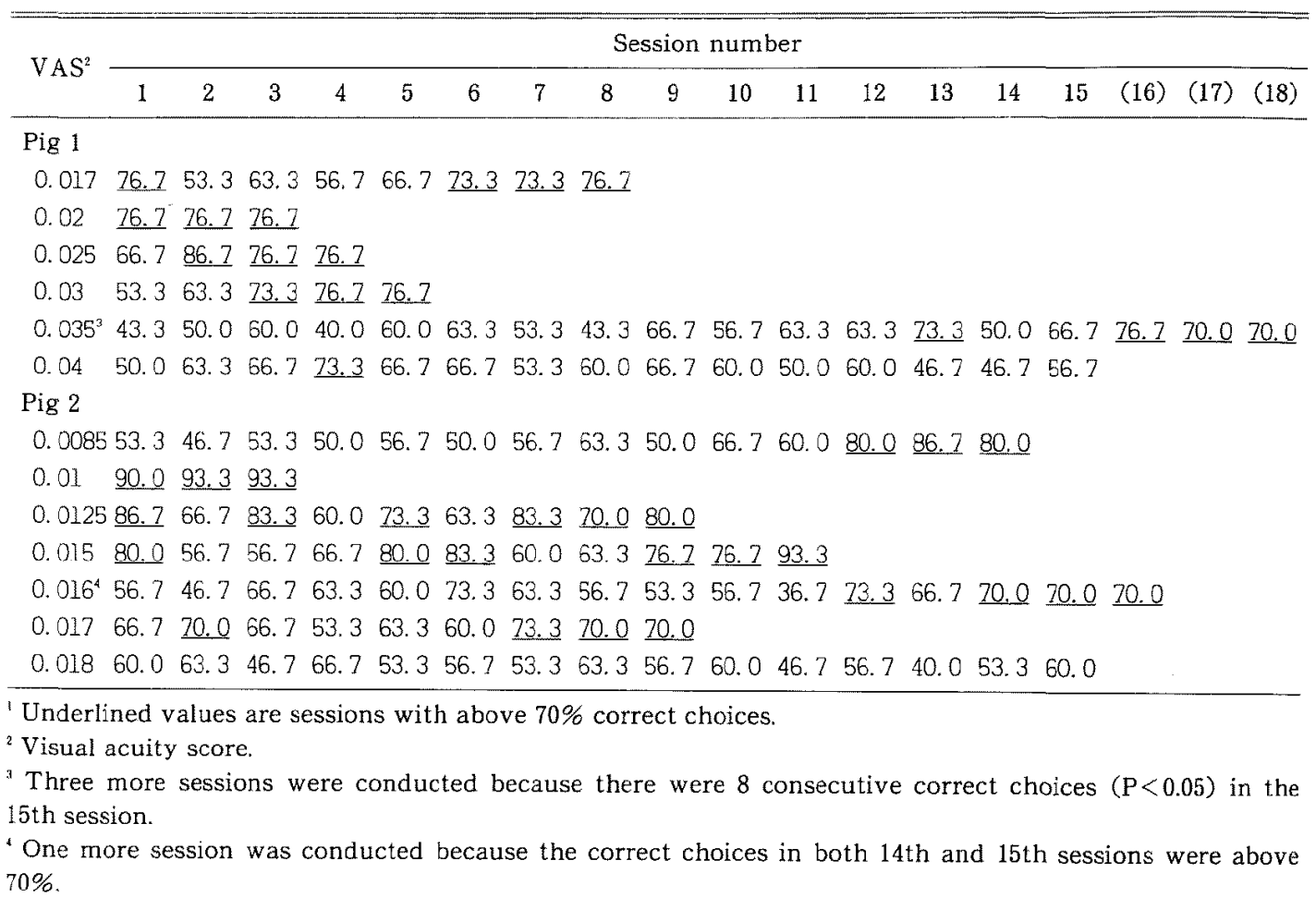

were 8 consecutive correct choices $(\mathrm{P}<0.05$, Grant Trend test) ${ }^{10)}$ in the 15 th session. Therefore, the test was continued and the correct choices in the following 3 sessions were above $70 \%$. For 0.04 , the responses were correct in more than 21 trials in only the 4 th session and no 3 sessions were consecutive. Therefore, the score of visual acuity for Pig 1 was determined as 0.035 . In the visual acuity score of 0.035 , the discrimination distance was $3.6 \mathrm{~m}$, and the sizes of the Landolt ring were $154 \mathrm{~mm}$ in overall diameter, and $31 \mathrm{~mm}$ for the widths of the ring itself and the square gap, respectively.

As the visual acuity of Pig 2 seemed to be relatively weak according to the result of training, the animal was tested from low score and increased in the score step by step. It required 14 sessions to reach the criterion of successful discrimination in first case of 0.0085 . In the next case of 0.01 , the pig reached the criterion after the first 3 sessions. For the scores of 0.0125 and 0.015 , it took 9 and 11 sessions to reach the criterion, respectively. For 0.016, as there were 21 correct responses in both 14 th and 15th sessions, one more session was conducted, and the correct responses in the session were $70 \%$. In the case of 0.017 , it took 9 sessions. However, the pig was not able to reach the criterion in the case of visual acuity score of 0.018. Therefore, the score of visual acuity for Pig 2 was determined as 0.017 . In the visual acuity score of 0.017 , the discrimination distance was $1.8 \mathrm{~m}$, and the sizes of the Landolt ring were $159 \mathrm{~mm}$ in overall diameter, and 32 $\mathrm{mm}$ for the widths of the ring itself and the square gap, respectively.

The results of the discrimination test for Pig 3 and Pig 4 are shown in Table 2. Pig 3 reached the criterion of successful discrimination after the first 3 sessions in the test for 0.014 , 
Visual Acuity of Pigs

Table 2. Rate of correct choices of Pig 3 and Pig 4 in varying visual acuity scores (\%)

\begin{tabular}{|c|c|c|c|c|c|c|c|c|c|c|c|c|c|c|c|}
\hline \multirow{2}{*}{ VAS $^{2}$} & \multicolumn{15}{|c|}{ Session number } \\
\hline & 1 & 2 & 3 & 4 & 5 & 6 & 7 & 8 & 9 & 10 & 11 & 12 & 13 & 14 & 15 \\
\hline \multicolumn{16}{|l|}{ Pig 3} \\
\hline 0.014 & 73.3 & 73.3 & 73.3 & & & & & & & & & & & & \\
\hline 0.02 & 66.7 & 73.3 & 70.0 & 70.0 & & & & & & & & & & & \\
\hline 0.024 & 73.3 & 80.0 & 60.0 & 70.0 & 70.0 & 70.0 & & & & & & & & & \\
\hline 0.03 & 66.7 & 70.0 & 60.0 & 50.0 & 60.0 & 63.3 & $\underline{76.7}$ & 70.0 & 70.0 & & & & & & \\
\hline 0.034 & 66.7 & 63.3 & 63.3 & 73.3 & 70.0 & 86.7 & & & & & & & & & \\
\hline 0.04 & 66.7 & 56.7 & 70.0 & 63.3 & 80.0 & 20.0 & 50.0 & 66.7 & 73. 3 & 83.3 & $\underline{70.0}$ & & & & \\
\hline 0.05 & 73.3 & 53.3 & 76.7 & 76.7 & 70.0 & & & & & & & & & & \\
\hline 0.06 & 73.3 & 56.7 & 80.0 & 70.0 & 76.7 & & & & & & & & & & \\
\hline 0.07 & 73.3 & 66.7 & 60.0 & 86.7 & 73.3 & 63.3 & 56.7 & 66.7 & 73.3 & 70.0 & 70.0 & & & & \\
\hline 0.08 & 76.7 & 63.3 & 60.0 & 56.7 & 60.0 & 63.3 & 56.7 & 63.3 & 70.0 & 46.7 & $\underline{73.3}$ & 53.3 & 53.3 & 46.7 & 53.3 \\
\hline \multicolumn{16}{|l|}{ Pig 4} \\
\hline 0.014 & 76.7 & 86.7 & $\underline{70.0}$ & & & & & & & & & & & & \\
\hline 0.02 & 66.7 & 73. 3 & 83.3 & 83. 3 & & & & & & & & & & & \\
\hline 0.024 & 86.7 & 73. 3 & 70.0 & & & & & & & & & & & & \\
\hline 0.03 & 63.3 & 63.3 & 60.0 & 46.7 & 66.7 & 66.7 & 66.7 & 63.3 & 63.3 & 56.7 & 63.3 & 20.0 & 80.0 & $\underline{80.0}$ & \\
\hline 0.032 & 56.7 & $\underline{80.0}$ & 80.0 & 76.7 & & & & & & & & & & & \\
\hline 0.034 & 80.0 & 70.0 & 70.0 & & & & & & & & & & & & \\
\hline 0.036 & 56.7 & 66.7 & 73.3 & 53.3 & 66.7 & 60.0 & 56.7 & 60.0 & 73. 3 & 60.0 & 50.0 & 63.3 & $\underline{70.0}$ & 73.3 & 63.3 \\
\hline
\end{tabular}

and the number of sessions increased gradually up to the visual acuity score of 0.04 (except for 0.034 which took 6 sessions). However, in the cases of 0.05 and 0.06 , it took only 5 sessions to reach the criterion. In the subsequent case of 0.07 , the pig took 11 sessions. For 0.08 , the responses were correct in more than 21 trials in 3 of 15 sessions, but no 3 sessions were consecutive. Therefore, the visual acuity score for Pig 3 was determined as 0.07 . For the visual acuity score of 0.07 at a fixed distance of $3.0 \mathrm{~m}$, the sizes of the Landolt ring were $64 \mathrm{~mm}$ in overall diameter, and $13 \mathrm{~mm}$ for the widths of the ring itself and the square gap.

Pig 4 reached the criterion of successful discrimination after less than the first 4 sessions in all tests, up to the visual acuity score of 0.024 . In the next case of 0.03 , it took 14 sessions. Then, Pig 4 was tested by increasing a score step by step as like as Pig 2. However, it took only 4 and 3 sessions to reach the criterion in the cases of 0.032 and 0.034 , respectively. In the case of 0.036 , the responses were correct in more than 21 trials in 4 of 15 sessions, but no 3 sessions were consecutive. The differences between the Landolt rings for 0.034 and 0.036 in the size of diameter and gap were only $7 \mathrm{~mm}$ and $1 \mathrm{~mm}$, respectively. Therefore, the pig was tested in the score of 0.04 by way of precaution, but there was no session with more than 21 correct choices. Then, the visual acuity score for Pig 4 was determined as 0.034 . For the visual acuity score of 0.034 at a fixed distance of $3.0 \mathrm{~m}$, the sizes of the Landolt ring were $132 \mathrm{~mm}$ in overall diameter, and $26 \mathrm{~mm}$ for the widths of the ring itself and the square gap.

\section{Discussion}

The visual field of pigs was measured by Prince ${ }^{16)}$. The report showed that the mean 

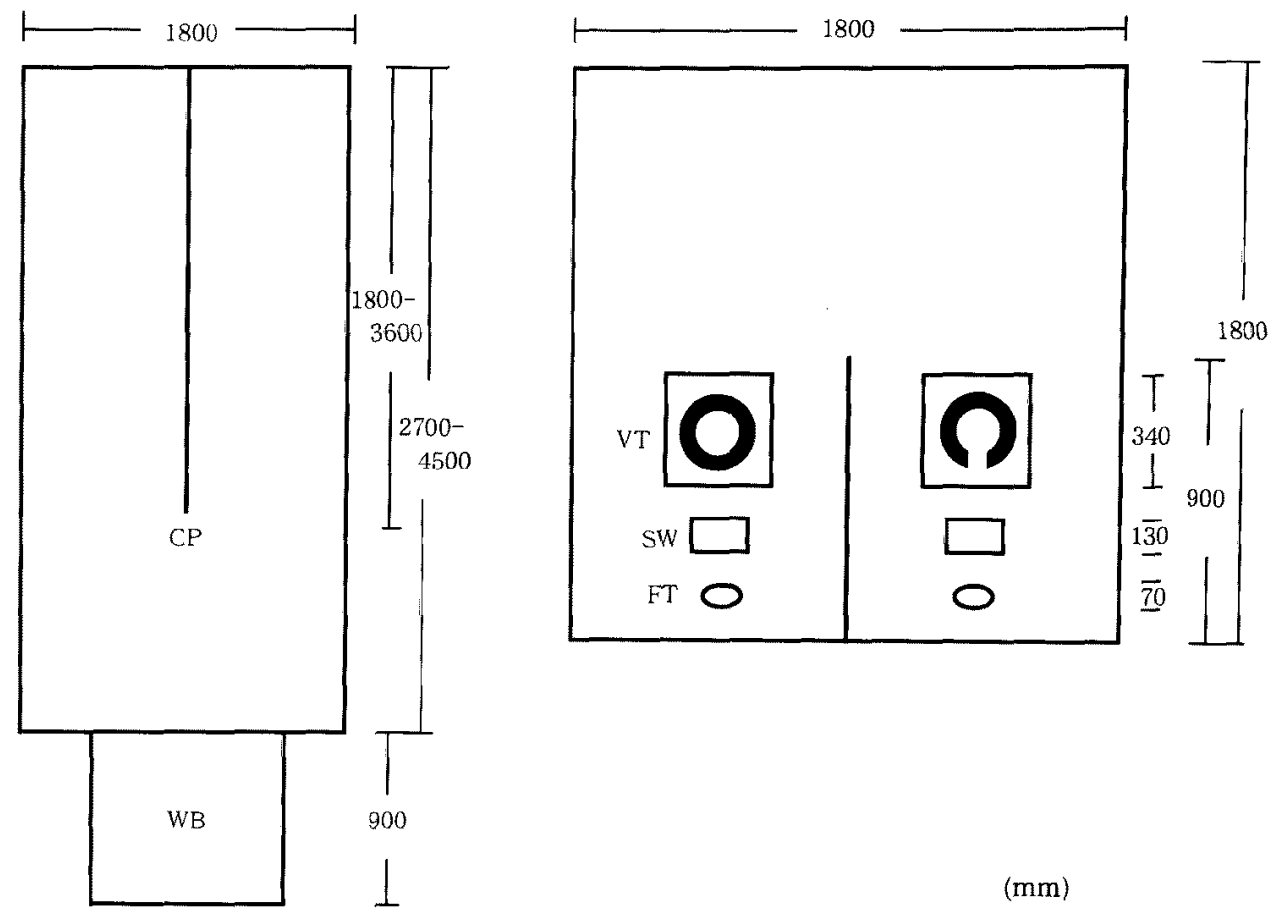

Fig. 1. Experimental room design (left) and the front of the room (right).

CP, choice point; WB, waiting box ; VT, visual target (left, ordinary ring as a positive stimulus ; right, landort ring as a negative stimulus).; SW, switch ; FT, feed trough.

binocular field just at eye level was $30-50^{\circ}$. As the experimental apparatus of the present study (Fig. 1) was made by referring to Prince's data, the size and arrangement of visual targets were considered to be suitable for discrimination learning in pigs.

Landolt and ordinary rings were used in this study based on the ruminants' visual acuity reports ${ }^{7.23)}$. However, it was very difficult for some pigs to learn the difference between those rings. It was effective to enlarge the gap of Landolt ring for those pigs to solve that problem. Therefore, some other targets (e.g. a grated vs. plain gray target, etc.) might be more suitable for pigs.

Four female and two castrated male pigs were used in this study, but the behavior of castrated males allowed no training. Rosengren ${ }^{17)}$ reported the same tendency on a male dog which was trained to discriminate among different colors. Male animals might be commonly hard to train the operant conditioning, therefore additional research will be necessary to clarify the differences of trainability and learning ability by sex.

The visual acuity of mammals except for primates is not well developed generally ${ }^{11}$. Entsu $^{6)}$ trained cattle to learn shape discrimination in order to determine their visual acuity, and reported that the score for Japanese Black cattle was between $0.045-0.083^{7)}$. Manda et $a l .{ }^{15)}$ also reported similar results for Holstein cows and Japanese Black cattle. We showed that the ability of sheep to resolve visual details is almost the same as in cattle, and seems relatively limited in comparison with humans ${ }^{23)}$. The results of the present study suggests that the visual acuity of pigs is also almost the same as the ruminant, or slightly poorer. 
On the other hand, it has been reported that the bighorn sheep can spot moving objects up to a distance of $1000 \mathrm{~m}^{83}$. The eye placement in the skull varies among species of mammals. This means that each species has its own evolutionary visual field and acuity. It might be more important for ruminant and also pigs to find faraway predators rather than to resolve lines and shapes.

In addition, it is known that visual resolving power in humans decreases under low light intensity ${ }^{12)}$, and that the visual acuity of one eye is different from that of both eyes ${ }^{19}$. These problems in pigs should also be studied.

\section{References}

1) Baldwin BA. Operant studies on shape discrimination in goats. Physiol. Behav., $23: 455-459$. 1979.

2) Baldwin BA. Shape discrimination in sheep and calves. Anim. Behav., 29 : 830-834. 1981.

3) Blakeman NE, Friend TH. Visual discrimination at varying distances in Spanish goats. Appl. Anim. Ethol., 16 : 279-283. 1986.

4) Eguchi $Y$, Tanida H, Tanaka $T$, Yoshimoto $T$. Color discrimination in wild boars. J. Ethol., $15: 1-7.1997$.

5) Entsu S, Ando F, Morozumi K. Control of behavior of young cattle under restricted grazing with night kraaling. III. Improvement of method for tending cattle by conditioned sound. Bull. Natl. Grassl. Res. Inst., 16 : 128-142. 1980. (in Japanese with English abstract)

6) Entsu $S$. Shape discrimination training for cattle with a Landolt ring. Jpn. J. Zootech. Sci., $60: 542-547$. 1989. (in Japanese with English abstract)

7) Entsu S, Dohi H, Yamada A. Visual acuity of cattle by the method of discrimination learning. Appl. Anim. Behav. Sci., 34 : 1-10. 1992.

8) Geist V. Mountain sheep : A Study in Behavior and Evolution. 383. University of Chicago Press. Chicago. 1971.

9) Gellermann LW. Chance orders of alternating stimuli in visual discrimination experiments. J. Genet. Psychol., 42 : 206-208. 1933.

10) Grant DA. Additional tables of the probability of "runs" of correct responses in learning and problem-solving. Psychol. Bull., 44 : 276-279. 1947.
11) Houpt KA, Wolski TR. Domestic Animal Behavior for Veterinarians and Animal Scientists. 1st ed. 3-31. The Iowa State University Press. Ames. Iowa. 1982.

12) Kamisaku H. Visual acuity. In : Handbook of Sensation and Perception in Psychology. (Wada Y, Oyama T, Imai S eds.) 250-262. Seishin Shobo. Tokyo. 1989. (in Japanese)

13) MAFF. Japanese Feeding Standard for Swine. 10-19. Central Assoc. Livestock Ind. Tokyo. 1993.

14) Manda M, Satou M, Kurohiji I. Behavioral response of cattle to electric-fence tapes in different colors. Jpn. J. Zootech. Sci., $60: 236-$ 239. 1989. (in Japanese with English abstract)

15) Manda M, Yamamoto $K$, Kurohiji I, Watanabe S. Behavioral evidence for eyesight acuity in cattle with a Landolt ring. Jpn. J. Livest. Management, 29:55-60. 1993. (in Japanese with English abstract)

16) Prince JH. The eye and vision. In : Dukes Physiology of Domestic Animals. (Swenson MJ ed.) 696-712. Cornal University Press. New York. 1977.

17) Rosengren A. Experiments in colour discrimination in dogs. Acta Zoologica Fennica, 121 : 1-19. 1969.

18) Schober HAW, Visual acuity. In : Encyclopedia of Occupational Health and Safety. Vol II L-Z. (Parmeggiany L ed.) 1473-1474. International Labour Office. Geneva, Switzerland. 1972.

19) Shitanaka K. Encyclopedia Heibonsha. 1st ed., Vol. 7. 770-771. Heibonsha. Tokyo. 1985. (in Japanese)

20) Siegel S. Nonparametoric Statistics for the Behavioral Sciences. 35-60. McGraw-Hill Book Company. New York. 1956.

21) Tanaka T, Asakawa K, Kawahara $Y$, Tanida $H$, Yoshimoto T. Color discrimination in sheep. Jpn. J. Livest. Management, 24 : 89-95. 1989.

22) Tanaka $T$, Sekino $M$, Tanida $H$, Yoshimoto $T$. Ability to discriminate between similar colors in sheep. Jpn. J. Zootech. Sci., 60 : 880-884. 1989.

23) Tanaka $T$, Hashimoto $A, T$ anida $H$, Yoshimoto T. Studies on the visual acuity of sheep using shape discrimination learning. J. Ethol., 13: 69-75. 1995.

24) Tanida H, Senda $K$, Suzuki S, Tanaka $T$, Yoshimoto $\mathrm{T}$. Color discrimination in weanling pigs. J. Anim. Sci. Technol. (Jpn.), 62 : 1029-1034. 1991. 
TANAKA, MURAYAMA, EGUCHI and YOSHIMOTO

図形識別学習法によるブタの視力測定

田中智夫 ・ 村山有美 $*$ 江口祐輔 - 吉本 正

麻布大学獣医学部，相模原市 229-8501

本研究は，ブタの視力について，ヒトにおける視力検查の基準を用いて検討した，6頭の育成豚（雙 4 頭, 去勢 2 頭) を供試し，試視力用のランドルト環と，その切れ目をなくした円図形とを用い，それぞれ 負およで正刺激として飼料と連合学漗させた。二者択一式の Y 字型迷路を自作し，図形の大きさまたは 困形までの距離変化させ，画図形の䡴別の可否から視力を判定した。左右の図形の交換は，ゲラーマ ン系列の乱数表に従って行った。 その結果, 去勢豚 2 頭は学習が成立せず, 視力測定ができなかったが, 雌豚 4 頭の視力值は, $0.017 \sim 0.07$ 範囲にあった.

日音会報，69 (3)：260-266, 1998

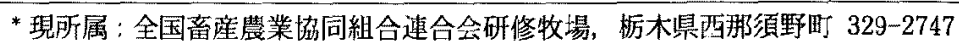

